\title{
Remote sensing investigation of sand mining in Wenzhou based on domestic satellite data
}

\author{
Wang Jie ${ }^{1}$, Yin Yaqiu ${ }^{1}$, Wang Yuhao ${ }^{2}$, $\mathrm{Li} \mathrm{Li}^{1}$, Chen Dong ${ }^{1}$ \\ ${ }^{1}$ China Aero Geophysical Survey \& Remote Sensing Center for Land and Resources, Beijing 100083 \\ ${ }^{2}$ China Siwei Surveying and Mapping Technology Co.Ltd. Beijing 100083
}

\begin{abstract}
Taking the domestic high-resolution satellite image data obtained in 2018 as the information source, the remote sensing image was processed, and part of the map spots were verified in the field. Combined with the natural environment, topography and geomorphology of Wenzhou City, the sand mining of Oujiang, Feiyun and Aojiang in Wenzhou City was investigated and monitored by remote sensing. Through the application research, the current situation of sand mining in Wenzhou City is found out, which can provide scientific basis for the government to make the next decision of sand mining restoration and management and the reasonable development and utilization planning of mineral resources.
\end{abstract}

\section{INTRODUCTION}

In order to carry out Xi Jinping's thought of ecological civilization, protect the ecological environment of rivers and lakes, and maintain economic and social harmony and stability, governments at all levels attach great importance to the management of sand excavation in the river [1], and the order of sand mining in the river has obviously improved. However, with the increasing protection of natural resources, sand and stone resources in the river become increasingly scarce resources, there are still violations, and the phenomenon of illegal mining occurs, which has brought a lot of impact on the ecological environment security of the river [2]. Therefore, it is urgent to strengthen the sand mining management, standardize the sand mining order, scientifically and orderly develop and utilize the sand resources, and maintain the river ecological environment.

With the development of remote sensing technology, various earth observation satellites continuously provide remote sensing images with different spatial resolution, time resolution and spectral resolution. Compared with traditional monitoring methods, using remote sensing technology has the advantages of low cost, timeliness and wide monitoring range [3]. Therefore, this paper uses multi-source domestic satellite remote sensing data to monitor the impact of sand mining on the environment in Wenzhou City, and combines with the mining right data in the past eight years for comparative analysis, to explore a scientific and efficient monitoring solution for sand mining in the river, in order to grasp the current situation of the impact of sand mining on the ecological environment in Wenzhou City, and to explore the governance measures for sand mining in the river in Wenzhou City.

\section{OVERVIEW OF THE STUDY AREA}

The main water systems in Wenzhou include Oujiang River, Feiyun River and chela river. Oujiang River is the second largest river in Zhejiang Province. It is a typical medium-sized mountain stream river. It originates from the top of Baishanzu pot at the junction of Longquan City and Qingyuan County in the south of Zhejiang Province. It flows from southwest to northeast, to Lishui and turns southeast. Along the way, it flows through Yunhe, Qingtian, Yongjia, Yueqing and Wenzhou. It is injected into the East China Sea with a total length of $388 \mathrm{~km}$ and a drainage area of $1790 \mathrm{~km} 2$ [4]; Feiyun River is one of the eight water systems in Zhejiang Province 1.It is the fourth largest river in Zhejiang Province and the second largest river in Wenzhou City. It originates from baiyunjian, Donggong mountain, Jingning She Autonomous County, Zhejiang Province, flows from west to East through Taishun County and Wencheng County, and enters the East China Sea in Shangwang Town, Southeast of Chengguan Town, Ruian City. The main stream is $193 \mathrm{~km}$ long, with a fall of $1200 \mathrm{~m}$ and an average gradient of $5.7 \%$. The basin covers an area of 3719 square kilometers, and there are abundant river sand resources in the river course between guiyanshan and koumeshangwang in the lower reaches of Feiyun River [5]. Aojiang River is one of the eight major water systems in Zhejiang Province, with a total drainage area of $158.4 \mathrm{~km} 2$ and a total length of $90 \mathrm{~km}$ of main stream. Most of the sand and stone resources in the Aojiang River Basin are distributed in the middle reaches of the Aojiang River (Shunxi - Shuitou) and its tributaries, mainly Shunxi, Yuexi, Huaixi, naocunxi, fengwoxi, etc. the distribution of sand and stone in the river channel below the fengwoxi outlet is relatively small [6] . (fig.1.) 


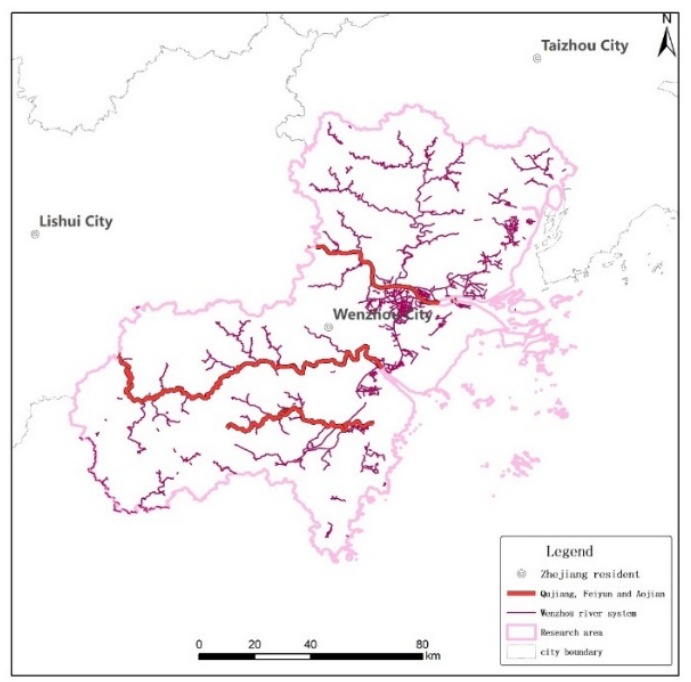

Fig.1. Geographical location map of the study area

\section{RESEARCH DATA SOURCES AND WORKING METHODS}

\subsection{Data source}

In order to study the effect of restoration and management, this paper uses the land change survey and remote sensing monitoring data of Wenzhou City in 2018 as the data source, and uses gj-1 $(0.5 \mathrm{~m}), \mathrm{BJ}-2(1 \mathrm{~m})$, gf-2 $(1 \mathrm{~m})$ and other multi-source domestic high-resolution satellite images for remote sensing dynamic monitoring. The main data source parameters are shown in Table 1 [7].

Table 1. Primary data source parameter

\begin{tabular}{|c|c|c|c|c|c|}
\hline $\begin{array}{c}\text { da } \\
\text { ta } \\
\text { ty } \\
\text { pe }\end{array}$ & $\begin{array}{c}\text { Satel } \\
\text { alte } \\
\text { altu } \\
\text { de } \\
/ \mathrm{km}\end{array}$ & $\begin{array}{c}\text { Radiatio } \\
\mathrm{n} \\
\text { quantific } \\
\text { ation } \\
\text { level }\end{array}$ & $\begin{array}{c}\text { spatial } \\
\text { resoluti } \\
\text { on/m }\end{array}$ & $\begin{array}{c}\text { Space } \\
\text { scann } \\
\text { ing } \\
\text { width } \\
/ \mathrm{km}\end{array}$ & $\begin{array}{c}\text { Spac } \\
\mathrm{e} \\
\text { satel } \\
\text { lite } \\
\text { revis } \\
\text { it } \\
\text { cycl } \\
\mathrm{e} \\
\text { /day }\end{array}$ \\
\hline $\begin{array}{c}\text { GJ } \\
-1\end{array}$ & 530 & 11 bit & $0.5 / 2$ & 12 & 4 \\
\hline $\begin{array}{c}\text { G } \\
\text { F- } \\
2\end{array}$ & 631 & 15 bit & $1 / 4$ & 45 & 5 \\
\hline $\begin{array}{c}\text { BJ } \\
-2\end{array}$ & 651 & 10 bit & $1 / 4$ & 24 & 1 \\
\hline
\end{tabular}

\subsection{Working method}

In this paper, a series of preprocessing researches on remote sensing image are carried out according to the relevant data features, such as ortho correction, optimal color synthesis, image registration, image fusion, image mosaic, etc., and the most suitable preprocessing scheme for sand mining information extraction is selected. On this basis, combined with field survey, visual interpretation and object-oriented automatic extraction technology are used to extract the active land occupation of sand mining, and The results were analyzed comprehensively. The technical route of this research is shown in Figure 2.

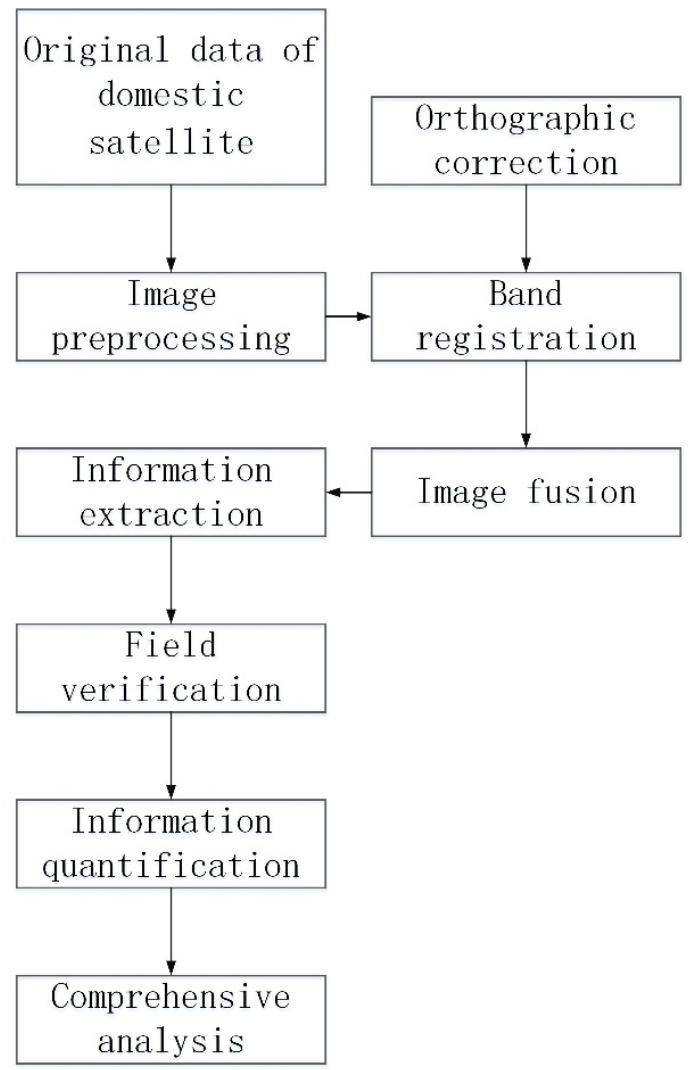

Fig.2 Overall technical flow chart

\section{REMOTE SENSING MONITORING RESULTS AND ANALYSIS}

\subsection{Mining right analysis}

According to the comparative analysis of mineral rights in Wenzhou issued by the Ministry of natural resources, it is found that in recent years, under the environment of highly valued environmental protection, the number of mining rights in Wenzhou has decreased significantly. According to the data, from 2012 to 2019, the total number of sand mining rights in Wenzhou decreased from 11 to 0 . As shown in Fig.3. 


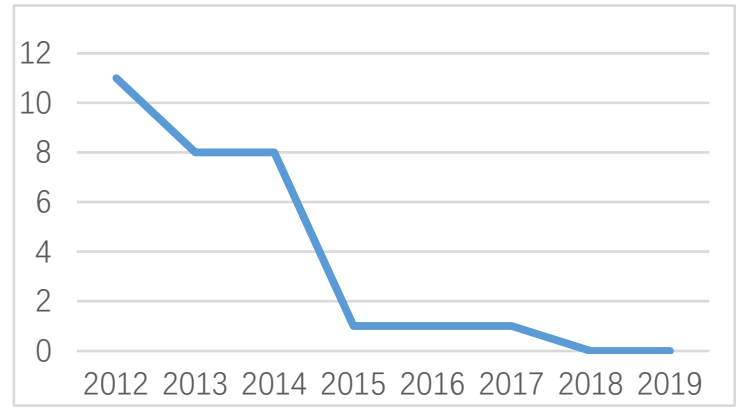

Fig.3 2012-2019 change of mining right

\subsection{Field verification}

In order to more accurately delineate the sand mining area and verify the accuracy of the interpretation results, we selected Oujiang and Aojiang two validation areas, and conducted field investigation on 60 interpretation points.

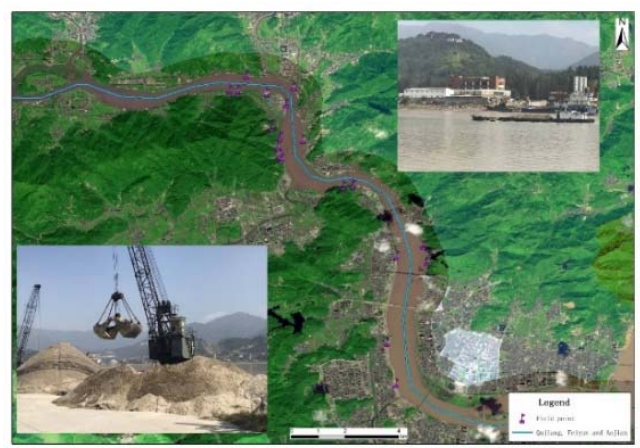

Fig.4 Oujiang remote sensing image and field photo

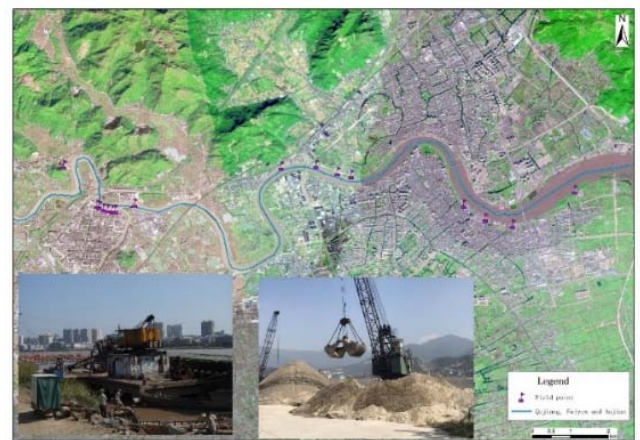

Fig.5 Aojiang remote sensing image and field photo

According to remote sensing images and field verification data, although the state has stopped issuing mining rights, there are still illegal sand mining activities in Oujiang and Aojiang.

\subsection{Result analysis}

Through remote sensing interpretation and field verification, the results show that there are still illegal sand mining activities in Oujiang and Aojiang, and no sand mining activities in Feiyun River. From the perspective of mining types, sand and pebble are the main mining methods; from the perspective of mining methods, water mining is the main mining method; from the perspective of mining scale, the scale is not large, and personal mining is the main mining method; from the perspective of mining time, the mining period is not long.

Oujiang and Aojiang sand quarries cover an area of 8.47 hectares, ore heaps cover an area of 5.11 hectares, concentrators cover an area of 23.49 hectares, office areas cover an area of 4.76 hectares, and restoration and treatment covers an area of 1.48 hectares. It can be seen that the recovery rate of sand mining in Wenzhou is $3.42 \%$, which is at a low level. The sand mining activities in Oujiang and Aojiang River basins have a serious impact on the stability of river regime and the safety of wading projects, as well as on the urban landscape.

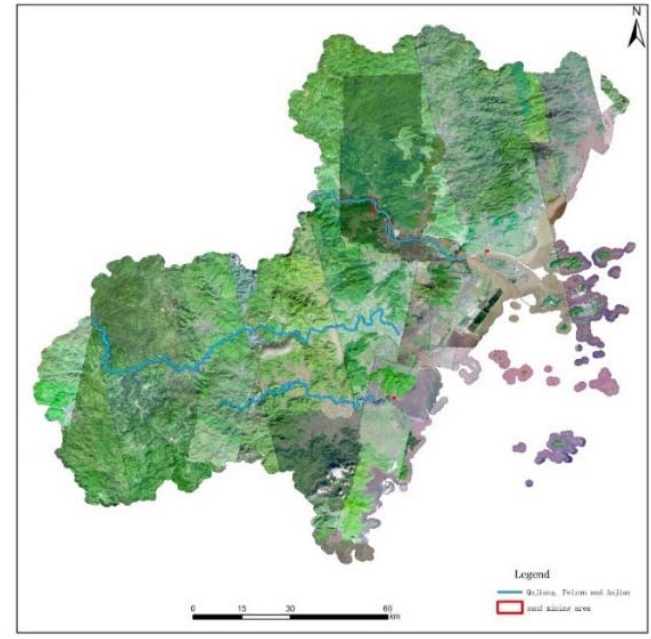

Fig.6 Map of sand mining in Wenzhou

Table.2 Sand mining in Wenzhou

\begin{tabular}{|l|l|l|l|l|l|l|}
\hline $\begin{array}{l}\text { Sand } \\
\text { minin } \\
\text { g area }\end{array}$ & $\begin{array}{l}\text { S } \\
\text { to } \\
\mathrm{p} \\
\mathrm{e}\end{array}$ & $\begin{array}{l}\text { Or } \\
\mathrm{e} \\
\text { he } \\
\text { ap }\end{array}$ & $\begin{array}{l}\text { Con } \\
\text { cent } \\
\text { rator }\end{array}$ & $\begin{array}{l}\text { Admin } \\
\text { istrativ } \\
\text { e Area }\end{array}$ & $\begin{array}{l}\text { Restorati } \\
\text { on } \\
\text { manage } \\
\text { ment }\end{array}$ & $\begin{array}{l}\mathrm{T} \\
\text { ot } \\
\text { al }\end{array}$ \\
\hline & 8. & 5.1 & 23.4 & & & \\
area & 4 & 1 & 9 & 4.76 & & $\begin{array}{c}4 \\
3.48\end{array}$ \\
& 7 & & & & & 3 \\
\end{tabular}

\section{EPILOGUE}

In this paper, the sand mining activities in Wenzhou City are monitored by remote sensing and analyzed by using the domestic high-resolution satellite data. The main research results are as follows:

(1) Remote sensing satellite data can real-time monitor the behavior of sand mining owners in the process of sand mining. There are still illegal sand mining activities in Oujiang and Aojiang, and no sand mining activities in Feiyun River. It is suggested that relevant policies, rules and regulations should be formulated according to this problem so as to make the sand and stone mining step by step. 
(2) The recovery rate of sand mining in Wenzhou is only $3.42 \%$, which is at a low level. It is suggested that the sand and stone resources should be reasonably developed and effectively utilized so as to achieve the organic combination of river sand mining and river basin management.

Fund project: The work is jointly funded by China Geological Survey Project "Remote Sensing Geological Survey and Monitoring of National Mine Environment Restoration and Governance Status" (No.: DD20190705) and "Remote Sensing Geological Survey and Monitoring of National Mine Development Status (No.: DD20190511).

\section{References}

1. Chen M S, Current situation of sand mining management in river course and legislative suggestions 20191

2. Yi J L, Analysis of sand mining management problems and Countermeasures in Anzhou 20191

3. Wang J,Remote Sensing Monitoring of Mine Geological Environment in Zhejiang Province Based on RS and GIS 20203

4. The variation law of human sea sand flux in Oujiang River Estuary 20121

5. Du P J,Characteristics and sources of suspended sediment transport in Oufei shoal, Wenzhou 201212

6. Ni L J, Analysis of the influence of sand mining activities on rivers and wading projects in Aojiang River Basin 20123

7. Wang J, Mine environment evaluation of Zhejiang Province Based on domestic high score satellite data 2019.11 